\title{
AVRUPA ÜLKELERİ VE TÜRKİYE UYGULAMALARI KAPSAMINDA KATILIMCI BÜTÇELEME YAKLAŞIMI
}

\author{
PARTICIPATORY BUDGETING APPROACH WITHIN THE CONTEXT OF EUROPEAN \\ COUNTRIES AND TURKEY
}

\section{Ufuk GERGERLİOĞLU $\mathbf{U}^{1}$ Mete DİBO ${ }^{2}$}

\section{$\ddot{O} \mathbf{z}$}

Katılımcı demokrasi uygulamalarının, temsili demokrasi yaklaşımını sürekli olarak ileriye taşıdığı veya taşıyacağı bilinen bir gerçektir. Bu anlayışın bir ürünü olan katılımcı bütçeleme uygulaması da, hükümetler tarafından gerçekleştirilecek hizmet ve yatırımların önceden belirlenmesinden hayata geçirilmesine kadar vatandaşların ve diğer paydaşların görüşlerine başvurulmasını esas almaktadır. Bilhassa yerel düzeyde kendisine daha iyi uygulama alanı bulan katılımcı bütçeleme yaklaşımı, genel olarak Mahalle Komiteleri ve Kent Konseyleri gibi yapılanmalar vasıtasıyla fiiliyata geçirilmektedir. 1980'li yılların sonuna doğru ilk olarak Brezilya'da uygulanmaya başlanan bu yaklaşım zamanla gelişmiş ve gelişmekte olan ülkelerin gündemlerine de girmeyi başarmıştır. Dünya ekonomisinde yaşanan daralmalar, ülkeleri kendi kaynaklarını kullanma konusunda daha dikkatli davranmaya yöneltmektedir. Bu durum, kaynakların daha verimli kullanılmasına önemli katkılar sağlayan katılımcı bütçeleme yaklaşımını daha popüler hale getirmektedir. Bu bilgiler 1şığında çalışmada, son yıllarda katılımcı bütçeleme uygulamalarında yaşanan gelişmelerin, farklı Avrupa ülkeleri ve Türkiye bağlamında açıklanması amaçlanmaktadır. Ülke seçimleri yapılırken akademik açıdan ulaşılabilir kaynak ve verilerden hareket edilmiş ve mümkün olduğunca yakın tarih ülke uygulamalarına değinilmeye çalışılmıştır.

Anahtar Kelimeler: Katılımcı Bütçeleme, Katılımcı Demokrasi, Aktif Vatandaşlık, Mahalle Komiteleri, Kent Konseyleri.

\begin{abstract}
It is a known fact that the practices related to participatory democracy have been constantly improving the representative democracy approach. Participatory budgeting which is a product of this understanding is based on consulting the views of citizens and other stakeholders for service and investment decisions that will be realized by the governments. In particular, the participatory budgeting approach applied at the local level is generally carried out through organizations such as neighborhood committees and city councils. Participatory budgeting was first implemented in Brazil towards the end of the 1980s. In time, this budgetary approach has also begun to be taken into the agendas of both developed and developing countries. Contraction in the world economy leads countries to be more careful about using their own resources. This makes the participatory budget approach more popular. In light of this information, this study aims to explain the recent developments in participatory budgeting in the scope of some European countries and Turkey. These countries have been chosen in accordance with the attainability of academic source and data. In addition, latest country practices have been addressed as far as possible.
\end{abstract}

Keywords: Participatory Budgeting, Participatory Democracy, Active Citizenry, Neighborhood Comities, City Councils.

\footnotetext{
${ }^{1}$ Yrd.Doç.Dr., Hitit Üniversitesi IiBF Maliye Bölümü, ufukgergerlioglu@hitit.edu.tr

${ }^{2}$ Yrd.Doç.Dr., Hitit Üniversitesi iïBF Maliye Bölümü, metedibo@hitit.edu.tr
} 


\section{GÍRiş}

Bilgi toplumu olmanın ve küreselleşmenin meydana getirdiği değişimler ile birlikte toplumun yönetilme biçimlerinde de bir takım farklılıkların meydana gelmesi kaçınılmazdır. Bilhassa 1980'li yıllardan itibaren kamu yönetimi anlayışı içerisinde filizlenen açıklık, hesap verilebilirlik, yönetişim gibi yeni kavramlarla birlikte kamu yönetiminde farklı yaklaşımların uygulanabilirliği tartışılmaya başlanmıştır (Ergen, 2012, s.332). Kamu yönetimi içerisinde gelişen ve benimsenen yaklaşımlardan bir tanesi de katılımcı bütçeleme anlayışıdır. $\mathrm{Bu}$ anlayış, bir taraftan katılımcı demokrasiye hizmet ederken diğer taraftan yerel sınırlar içerisinde yaşayan vatandaşların kendileri ile alakalı konularda siyasi açıdan söz söyleme hakkına sahip olmasının önünü açmaktadır (Özen ve Yontar, 2009, s.292). Aynı zamanda bu anlayış, temsili demokrasi yaklaşımından katılımcı demokrasiye geçişi kolaylaştıran bir siyasi araç olarak da değerlendirilmektedir (Yalçın, 2015, s.326). Bununla birlikte katılımcı bütçeleme anlayışı, yerel yönetişim kavramı ile de bütünlük ortaya koymaktadır (Sakınç ve Bursalığlu, 2014, s.9). Hatta katılımcı bütçeleme sürecini, denenmiş ve somut bir yönetişim uygulaması olarak da tanımlamak mümkündür (TEPAV, 2007). Öte yandan bu bütçeleme anlayışı, mali yerelleşme yaklaşımının temel kriterlerinden biri olarak da ele alınmaktadır (Çobanoğulları ve Yereli, 2017, s.123).

Birçok önemli kamu yönetimi kavramının besleyicisi ve tamamlayıcısı olan katılımcı bütçe yaklaşımı, literatürde özellikle son on yıldır farklı açılardan değerlendirmeye tabi tutulmaktadır. $\mathrm{Bu}$ bağlamda bu çalışma, katılımcı bütçe uygulamasında yakın zamanda yaşanan değişimleri, Avrupa'nın farklı bölgelerindeki ülke uygulamaları çerçevesinde değerlendirmeyi amaçlamaktadır. Tüm bu bilgiler ışığında öncelikle teorik açıdan katılımcı bütçeleme kavramına değinilmektedir. Arkasından da katılımcı bütçelemeyi uygulayan Avrupa ülke örneklerine yer verilmektedir. Bu çalışmada Türkiye'nin katılımcı bütçeleme sürecinde hangi noktada olduğuna dair de değerlendirmelerde bulunulmaktadır. $\mathrm{Bu}$ değerlendirmeler, doğrudan doğruya görüşülen resmi kurum yetkililerinin vermiş olduğu bilgileri temel almaktadır.

\section{KATILIMCI BÜTÇELEME YAKLAŞIMININ TEORİK TEMELLERİ}

Katılımcı bütçeleme, hükümetlerin bütçe hakkında karar alma süreçlerine toplum bireylerinin dâhil edildiği bir yaklaşımı ortaya koymaktadır. Bu bütçeleme yaklaşımı, bütçeye yönelik kararlarda sadece bireylerin değil aynı zamanda sivil toplum kuruluşlarının ve hükümetlerin de sürece dâhil olarak bütçe açısından verimli sonuçların açığa çıkabileceğini savunmaktadır. Dolayısıyla bu olgu, toplum içinde bulunan farklı yapıdaki gurupların düşüncelerini dikkate alarak katılımcılığı desteklemektedir. Bu sürecin bir sonucu olarak da devlet kaynaklarının etkin bir biçimde kullanımının sağlanması mümkün olabilmektedir. Ayrıca bu yaklaşımı benimseyen hükümetler, bütçelemede şeffaflığın sağlanmasına ve dolayısıyla yozlaşmanın devlet kurumları içerisinde azalmasına da katkı sağlamaktadırlar (Wampler, 2007, s.21). Öte yandan katılımcı bütçelemenin bireylerin fikirlerini açıkça beyan edebilmelerine imkân tanıması, bu yaklaşımın demokrasi ile ilişkilendirilmesine de neden olmaktadır (UN-HABITAT, 2004, s.20). Bununla birlikte literatürde katılımcı bütçelemenin katılımcı demokrasi ile nasıl bir etkileşim içerisinde olduğu da tartışılmaktadır (Lerner, 2010, ss.249-250).

Katılımcı bütçeleme yaklaşımı, kent fakiri toplulukların kendilerini ifade etme veya hükümetler ve uluslararası ajanslar ile işbirliği yapma kabiliyetlerini geliştirme potansiyeline sahiptir. Katılımcı bütçeleme anlayışına ilişkin bu potansiyel, politikacıları yeniden düşünmeye sevk etmekte ve onlara gayretlerini ortaya koyabilecekleri bir alan sunmaktadır (Worldwatch Institute, 2007, s.181). Aynı zamanda bu yaklaşım, vatandaşların kendi şehirlerinin gelecek planları hakkında görüş bildirmelerine ve onların kendi şehirleri, 
sokakları, mahalleleri hakkında fikir beyan etmelerine zemin hazırlayarak yerel hükümetleri tek taraflı karar verme eğilimlerinden uzaklaştırmaktadır (Xavier Pinto Coelho, 2013, s.74). Tüm bunlara ilave olarak katılımcı bütçeleme yaklaşımı, iletişim ve bilgi paylaşımını güçlendirerek toplum ruhunun ve toplumda dayanışmanın artmasına da yardımcı olmaktadır. Ayrıca demokratik tabanlı iyi bir yönetişimin sağlanması için etkin bir araç olan bu yaklaşım, toplumda ortak bir vizyonun meydana getirilmesine de zemin hazırlamaktadır (UNHABİTAT, 2008, s.11). Bu yaklaşımın özellikle iyi bir yönetişimin ortaya çıkmasına yardımcı olması, onun sosyal gücünü de göstermektedir. Aslında katılımcı bütçeleme yaklaşımı ile yönetişim birbirini besleyerek toplumda çok daha demokratik bir atmosferin oluşmasına ön ayak olmaktadır.

Yönetişimin toplumun her kesimine katk1 sağlaması, kaynakların optimal dağılımına yönelik bir dürtü oluşturmakta ve bilhassa toplumda dezavantaja sahip grupların yaşam standartlarında daha pozitif bir etkinin meydana gelmesine yardımcı olmaktadır (Ghosh vd., 2011, ss.65-66). Bunun ötesinde yerel yönetişim kavramı, yerel yönetim olgusunun kapsamını aşmakta (Shah ve Shah, 2006, s.1) ve yerel politikaların yeniden tasarlanmasına yönelik bir ortamın oluşmasına destek sağlamaktadır (Cole ve John, 2001, s.9). Ancak bu iyi sonuçlar vatandaşları koruyup kollayan bir hukuk sisteminin mevcudiyetinde söz konusu olabilmektedir (Eissel ve Grasse, 2011, s.67). Elbette ki bu bütçeleme yaklaşımının da kabul görmüş kendine has bir takım temel argümanları bulunmaktadır.

İlgili bütçeleme yaklaşımına yönelik bu argümanlar, esas olarak bilgi paylaşımının yapıldığı bilgilendirme oturumları, mahalle meclisleri, bütçe temsilcileri ve seçim olmak üzere dört kısımdan oluşmaktadır. Bilgilendirme oturumları, farklı hükümet programlarının etki ve maliyetlerine yönelik olarak vatandaşların bilgiye erişimlerinin sağlanmasını ifade etmektedir. Mahalle meclisi, yerel bütçesel ihtiyaçlarının ayrıntılı bir biçimde ele alındığı bir görünüm sergilemektedir. Bütçe temsilcileri, bir taraftan uygulanabilir bütçe önerilerinin taslağını hazırlarken diğer taraftan hükümet yetkilileri ile doğrudan etkileşim sağlamaktadırlar. Bu sürecin sonunda da finansmanı karşılanabilecek nitelikteki projelerin geniş halk kitleleri tarafından seçimi gündeme gelmektedir (Gilman, 2016, ss.7-8). Katılımcı bütçe uygulamalarının Avrupa ülkeleri bağlamında değerlendirilmesine geçilmeden önce son olarak bu yaklaşımla alakalı topluma, bireylere ve hükümetlere yönelik hangi kavramsal çıkarımların söz konusu olduğunun izah edilmesinde yarar görülmektedir.

Katılımcı bütçeleme yaklaşımının, hükümetlerin sunduğu hizmetleri verimli hale getirdiği bilinmektedir. Katılımcı bütçeleme yaklaşımı açısından verimlilik sağlayıcı etmenleri; hesap verilebilirlik, şeffaflık, vatandaş ve hükümet arasında güvenin inşa edilmesi, yerel kaynakların daha iyi kullanılması, kayırmacılığın ve yozlaşmanın üstesinden gelinmesi, hükümetler üzerinde kontrol olanağının sağlanması, kamu harcamaları üzerinde ortak karar ve ortak yönetim anlayışının etkili olması, kamu finansmanına yönelik olarak halkın bilgilendirilmesi, kamu yönetimine yönelik etkinliğin geliştirilmesi biçimde sıralamak mümkündür. Diğer taraftan bu yaklaşım, vatandaşlık ve demokrasinin geliştirilmesi yönünden de bir takım hususlar ortaya koymaktadır. Bu hususlar, vatandaş katılımını teşvik etmek, demokrasiyi güçlendirmek, sosyal bağları kuvvetlendirmek, şehrin küresel vizyonunu geliştirmek şeklinde sıralanabilir. Bununla birlikte, bu yaklaşım, topluma yönelik bazı geliştirici imkânlar da sunmaktadır. Bu imkânlar ise sırasıyla; sosyal kaynaşmanın ve şehir dayanışmasının arttırılması, sosyal eşitsizliklerin ele alınması, farklı sosyal grupların taleplerinin sunumlarına firsat verilmesi, farklılıkların hoş görülmesi ve barış ile tahammülün teşvik edilmesi şeklindedir (Xavier Pinto Coelho, 2013, s.76). 


\section{AVRUPA ÜLKELERINDE VE TÜRKIYE'DE KATILIMCI BÜTÇELEME UYGULAMALARI}

Katılımcı bütçeleme, ilk olarak Brezilya'da sosyal dışlanma, sosyal yozlaşma ve kayırmacılık sorunlarının üstesinden gelmek adına 1980'li yılların sonunda uygulama alanı bulmuş bir yaklaşım olarak ele alınmaktadır (Blore, 2004, s.98). İşçi Partisinin Brezilya'da Porto Alegre'de şehir yönetimini ele geçirmesinden kısa bir süre sonra hayata geçirilen katılımcı bütçeleme programı, şehir halkına kendi şehirlerinin geleceklerine yönelik bir irade ortaya koyma hakkı tanımıştı (The World Bank, 2014, s.14). Şehir halkının çoğu Porto Alegre bölgesinde yaşayan yoksul insanlardan oluşmaktaydı (Baiocchi, 2009, s.115). Böylelikle farklı yerleşim yerlerinden farklı çıkarlara sahip vatandaşlara, bir araya gelerek yatırım ve harcama önceliklerini belirleme yetkisi verilmiş oldu. Bu süreçten önce borçluluk, yoksulluk gibi bir takım sosyal meselelerin çözümü konusundan kaynak sıkıntısı yaşayan şehir, katılımcı bütçeleme programı ve bu programa ilave mali reformlar sayesinde ilerleyen yıllarda önemli başarılara imza attı (The World Bank, 2002, ss.173-174). Bu bütçeleme programı, bu ülke ile sınırlı kalmayarak Latin Amerika'da ve diğer ülkelerde uygulanmaya başlanmıştır (Bredenoord vd., 2014, 219).

$\mathrm{Bu}$ başlık altında ilk olarak katılımcı bütçeleme yaklaşımı, Avrupa ülkeleri bağlamında ele alınmaktadır. Bu kapsamda sırasıyla, Fransa (Paris), Portekiz (Lizbon), İspanya (Sevilla), İngiltere (Londra), Polonya (Sopot) ve Almanya'da (Berlin) uygulanmakta olan katılımcı bütçelemeye yönelik girişimlerden bahsedilmektedir. $\mathrm{Bu}$ değerlendirme yapılırken de mümkün mertebe günümüze yakın uygulamalara değinilmektedir. Burada son olarak Türkiye'de son yıllarda uygulanan katılımcı bütçeleme programlarına ilişkin bilgilere yer verilmektedir.

\subsection{FRANSA, Paris}

22 Ekim 2006'da Sosyalist aday Segolene Royal, kamu politikalarını değerlendirmek üzere rastlantısal olarak seçilmiş bir halk jürisinin oluşturulması önerisinde bulunmuştur. $\mathrm{Bu}$ öneriye tüm siyasi partilerden yoğun itirazlar gelmiştir. Bu öneri, Nicolas Sarkozy’nin de içinde bulunduğu muhafazakar sağ parti mensuplarınca aşırı popülist olarak değerlendirilmiş, darbeci ve devrimci bazı tarihi kişiliklerle ilişkilendirilerek ağır şekilde eleştirilmiştir. Aynı zamanda bu öneri, sol kanattaki siyasiler tarafından da demagojik bir politika olarak ele alınmış ve bu öneriye aşırı sağcı Le Pen ve komünist Mao Zedong'dan esinlenilmiş bir düşüncenin ürünü olduğu yönünde eleştiriler yapılmıştır. Bununla birlikte, Fransa Cumhuriyeti'nin geleneksel politik kültüründe, vatandaşların siyasi sorunlara dâhil edilmesine ve özellikle de bu katılımın mikro-yerel düzeydeki girişimlerin ötesine geçmesine şüpheyle yaklaşılmıştır (Röcke, 2014, s.59).

Ancak bu yaklaşım, 2000'li yıllarda Merkez Sağ Partinin kurulması, sol siyasi yelpazenin en büyük partisi olan Sosyalist Partinin yanı sıra farklı küçük radikal grupların ve 2007 yılında François Bayrou tarafindan oluşturulan Demokratik Hareketin ortaya çıkmasıyla değişmiştir. Bu ideolojik dönüşümle, yönetimde yerelleşme hareketi başlamış, devlet ve halk arasındaki mesafeli ilişkide bakış açısı değişmiş ve bunun yerine halka yakınlık düşüncesi ile halkın siyasi meselelere katılımına vurgu yapılmıştır (Röcke, 2014, ss.61-62).

Yönetim anlayışında yaşanan bu değişimin bir göstergesi, katılımcı bütçeleme konusunda ortaya konan yoğun çabalardır. Özellikle 2014 yılında, başkent Paris'e Belediye Başkanı olarak seçilen Anne Hidalgo'nun öncülügünde, katılımcı bütçelemenin hayata geçirilmesine yönelik yapılan girişimler dikkat çekici niteliktedir. Bu girişimlerin en önemlilerinden birisi, ileri sürülen 15 geniş çaplı projenin belirlenmesinde karar verici olarak halkın davet edilmesidir. Bahse konu halk çağrısı, Fransa'nın katılımcı bütçeleme konusunda 
ne derece istekli olduğunu açıkça göstermektedir. 20 milyon Euro düzeyinde bir kaynağın 15 proje için nasıl dağıtılacağı konusunda hem internet üzerinden çok geniş kapsamlı bir davet yapılması hem de bireylerin seçim yapmalarına yardımcı olabilecek seçim sandıkları oluşturulması, Paris yerel yönetiminin bu yöndeki isteğinin bir kanıtı niteliğindedir. Önceliklerin belirlenmesine yönelik yapılan bu girişimin sonucunda, seçime katılan Paris halkının 15 projenin ancak 9'u için onay verdiği görülmektedir. Resmi yetkililer bu nitelikteki seçimlerin Paris şehri için devam edeceğini ve bu kapsamdaki projeler için ayrılan fonların zamana bağlı olarak 500 milyon Euro'ya kadar ulaşacağını ifade etmektedirler (Veron, 2015). Belki bu noktada internet ortamındaki katılımın Paris halkının görüşlerini ne derecede yansıttığı sorusu akla gelebilir.

2013 resmi verilerine göre Fransız halkının \%80'inin evinde bilgisayar mevcuttur. Ancak buna rağmen daha yaşlı insanların varlığı da göz önünde bulundurulmuş, geleneksel bir oylama aracı olan seçim kutuları, en yüksek katılımın sağlanması için hazırlanmıştır (Napolitano, 2015).

\subsection{PORTEKİ, Lizbon}

Portekiz'de katılımcı bütçeleme uygulaması, Lizbon şehir konseyi içerisindeki bir grup teknisyenin ön ayak olması ile 2008 yılında Lizbon'da hayata geçirilmiştir. Bu teknisyenler öncelikle katılımcı bütçeleme konusunda başarılı olan Brezilya uygulamasını incelemişler ve ardından halk tarafından rağbet gören girişimler için belediye bütçesinin belli bir oranının ayrılmasına yönelik düşüncelerini ortaya koymuşlardır. Bu teknisyen ekip, politikacıları ikna etmek adına kapsamlı bir çalışma hazırlamış ve böyle bir çalışmanın toplum ihtiyaçlarının belirlenmesine yardımcı olabileceğini savunmuşlardır. Bu çabalar meyvesini vermiş ve talep gören projelere yönelik yerel bütçe kaynaklarından \%5'lik bir oranın ayrılması kabul edilmiştir. Sonrasında bu yeni yaklaşımın nasıl uygulanabileceğine ilişkin bir yol haritası belirlenmiştir. Yıllar itibariyle bu yeni bütçe uygulamasına katılımlarda hissedilir bir artış kaydedilmiştir (Standring, 2014). Bilhassa projelerin değerlendirilmesi kapsamında, internet ortamındaki katılımda ve ortaya konulan projelerin sayısında hatırı sayılır bir artış gözlemlenmiştir (Allegretti ve Antunes, 2014, s.4). Katılımcıların önerisiyle, ev işletmeciliğinin firmalara dönüşmesine yönelik girişimciliğin desteklenmesi görüşü, 2011 yılında büyük destek bulmuştur (Standring, 2014).

\section{3. İSPANYA, Sevilla}

İspanya, katılımcı bütçeleme programını başarıyla uygulayan ülkelerin başında gelmektedir. Ülkenin, yaklaşı 700 bin nüfusa sahip olan kenti Sevilla'daki kent sakinleri, 2004 'ten beri kendi şehirlerinin geleceğini belirlemekte ve yapılan mahalli harcamaların hangi alanlara tahsis edileceği konusunda karar vermektedirler. Sevilla halkı proje önerilerini mahalle meclislerinde veya internet ortamında sunmaktadırlar. Seçilmiş bütçe temsilcileri, bir dizi görüşmenin ardından, katılımcı bütçeyi, uygulanması için belediye yetkililerine teslim etmektedirler (PBP, 2016). Sevilla'nın katılımcı bütçe uygulamasıyla ilgili olarak, 2004-2009 yıllarına ait geçmiş yıl verileri dikkate alındığında, katılımcı bütçeye iştirak edenlerin sunduğu öneri sayısının toplamda 14.577 ve farklı oturumlar için birey toplantı katılımının toplam saat miktarının neredeyse 175 bin olduğu görülmektedir (Cabannes, 2015, s.130). Katılımcı bütçe programının 2004 yılından beri uygulandığ 1 Sevilla'da halk, 2004-2013 yılları arasında kendi şehirlerinin proje ve programlarına yönelik olarak yapılan mahalli harcamaların yaklaşık \%50'sini belirlemiştir. 


\subsection{INGILTERE, Londra}

İngiltere'de katılımcı bütçeleme kapsamında yapılan ilk çalışmalar, 2005 yılına dayanmaktadır. Londra'ya bağlı Harrow'da katılımcı bütçeleme sürecini başlatmak gayesiyle 300 Harrow yerleşim yeri sakini, şehrin önceliklerinin ve şehre ilişkin alternatiflerin neler olabileceği konusunda fikir ileri sürmüşlerdir. Şehrin geleceğini ilgilendiren bu girişim, bir ilk olma özelliği göstermekteydi. Açık bütçe toplantısı olarak nitelendirilen ve kent konseyi tarafından organize edilen bu girişimin resmi bir hüviyeti bulunmamaktaydı. Bu girişim, belirli bir organizasyon dâhilinde yönetilmekteydi. Bu organizasyonun üst organı, açık bütçe idare grubuydu. $\mathrm{Bu}$ idare grubu, kent konseyinin alt komitesi biçiminde çalışacaktı. Aynı zamanda bu grup, kent için ayrılacak kaynakların sağlanması ve katılımcı bütçeleme sürecinin genel anlamda yönetilmesi görevini üstlenecekti. Öte yandan bu grup tarafindan belirlenen açık bütçe idare kurulu, katılımcı bütçeleme sürecinin gözlemlenmesi, tasarlanması gibi görev sorumluluklarını üzerine alacaktı. Bu yapılanma, ilgili organizasyonun idari ayağını oluşturmaktaydı. Bu idari yapılanma şemsiyesi altında da Harrow sakinlerinin açık bütçe toplantıları ve panelleri yapılacaktı (SQW Consulting, 2007).

İşte bu organizasyon çerçevesinde yapılan katılımcı bütçeleme girişimi, memnuniyet verici bir takım sonuçlar ortaya koydu. Bu sonuçlar, organizasyon içerisinde yer alan Harrow sakinlerinden elde edilen bilgileri kapsiyordu. Harrow sakinlerinin \%90'1, bu girişimi, iyi veya çok iyi olarak değerlendirdi. Bu sakinlerin \%74'ü ise bu girişimi ilerleyen yıllarda tekrarlanabilir olarak nitelendirdi (OECD, 2007, s.150). Bu girişimin yapıldığg dönemi izleyen yakın zamanda, katılımcı bütçeleme çalışmaları için bir uluslararası merkez oluşturuldu. Bunu takiben Mart 2006 - Nisan 2007 yılları aralığında İngiltere'nin kuzey bölgesinde katılımcı bütçelemeye yönelik bir çalışma yapıldı (2008, Blakey, s.63). 2009 yılında İngiltere'nin Norfolk Bölgesinde vatandaşların katılımı sağlanarak yapılan katılımcı bütçeleme girişimleri, bölge vatandaşlarına 200 bin sterlinlik bir bütçe için öncelikleri belirleme imkânı sunmuştur (PB Unit, 2010). İngiltere'de, çok yakın tarih süreci içerisinde, Leed, East Sheppey, Luton, Buckfastleigh gibi birçok yerleşim yerinde katılımcı bütçeleme uygulamasının hayata geçirilmesi için bir takım girişimlerde bulunulmuştur (PB Network, 2007).

\subsection{POLONYA, Sopot}

Polonya'da katılımcı bütçeye benzer bir girişim Plock kentinde ortaya çıkmışsa da katılımcı bütçeye ilişkin asıl uygulama, 2011 yılında, Baltık sahilinde yer alan ve küçük bir şehir olan Sopot'da gerçekleşmiştir. Resmi anlamda ve yaygın olarak kabul gören bu proje, Polonya'daki ilk katılımcı bütçe projesi olarak dikkate alınmaktadır. Ocak 2014 itibariyle katılımcı bütçe uygulamalarının, yaklaşık 80 şehri kapsadığı görülmektedir. Krakow, Lodz, Wroclaw, Poznan ve Gdansk bu şehirler içerisinde yer almaktadır (Keblowski ve Van Criekingen, 2014, s.369).

Polonya'da yürürlükte olan mevzuata göre belediye başkanı, belediye bütçesinin hazırlanması ve yürütülmesinden sorumludur. Kent Konseyi ise her yıl belediye başkanının bütçe önerisini resmen onaylamaktadır. Bu Konseyin öneri üzerinde değişiklik yapma yetkisi de bulunmaktadır. Hem Konsey hem de belediye başkanı doğrudan halk oylamasıyla seçilmektedir (Keblowski ve Van Criekingen, 2014, s.372).

Sopot'a yönelik yapılan katılımcı bütçeleme uygulaması, elle tutulur sonuçlar doğurmuştur. 2011-2013 yılları arasında 67 şehir ve 140 ilçe çapındaki öneriler, Komite tarafından olumlu bulunmuştur. Şehir bazındaki önerilerin 14'ü ve ilçe bazındaki önerilerin 61 'i ise halk oylaması yoluyla seçilmiştir. Şehirlerde seçilen öneriler; atık dönüşüm sistemi ve geri dönüşüm kutuları, yeşil alanların iyileştirilmesi, sokakların yenilenmesi (bisiklet yollarının yapılması gibi), 19. yüzyıldan kalan yapıların dış cephelerinin yenilenmesi, Sopot 
ve Gdansk'1 birbirine bağlayan otobüs hattının kurulması, konut kooperatifleri ve küçük işletmeler için finansal desteğin sağlanmasını içermektedir. 2013 yılında katılımcı bütçeyle halk oylamasına sunulan vatandaş önerilerinin sayısı 77 , halk oylaması sonucu hayata geçirilmek üzere seçilen önerilerin sayısı ise 26'dır. Sopot'un toplam bütçesi içerisinde katılımcı bütçenin payı \%1.38, yatırım bütçe harcamaları içerisindeki payı da \%6.07 olarak gerçekleşmiştir (Keblowski ve Van Criekingen, 2014, ss.375-376).

\subsection{ALMANYA, Berlin}

90'lı yılların sonunda Berlin'de yaşanan işsizlik artışı ve yoksulluk üzerine şehir yönetiminin Sosyal Kent olarak adlandırılan toplumsal kent onarım programını başlatması, halkın karar mekanizmalarına katılmasında başlangıç noktası olmuştur. 1999 yılından itibaren uygulanmaya başlanan bu programın arka planını, Fransa ve Birleşik Krallık'ta uygulanan benzer programlar oluşturmuştur. Bu Program ile şehirde yaşanan problemlerle mücadele etmek üzere ilave fonların belirli alanlara aktarılması, yerel ortaklık kurullarının oluşturulması ve yerleşiklerin doğrudan katılımının sağlanması hedeflenmiştir (Röcke, 2014, s. 135).

Berlin, ülkede katılımcı bütçenin uygulandığı ilk büyük şehir olma özelliğine sahiptir. Daha da önemlisi Berlin şehri, katılımcı bütçelemenin Porto Alegre modelinden etkilenen sivil toplum aktivistleri tarafindan siyasi gündemde yer bulduğu ilk Alman şehridir. Katılımcı bütçeleme Berlin'in 264.000 nüfuslu Lichtenberg ve 249.000 nüfuslu Marzahn yerleşim yerinde uygulanmıştır (Röcke, 2014, ss.133-140).

Lichtenberg, 2005 yılında katılımcı bütçenin ortaya çıktığı ilk bölgedir. Bu bölgede, mahalle diyalogları, halka açık toplantılar ve çevirim içi hizmetlerle, yerleşim yeri halkının önerilerini sunup tartışabileceği alanlar meydana getirilmiştir. Halk, ilgili yerleşim yerindeki oylama zamanlarında çevirim içi ya da doğrudan oylamaya katılabilmektedir. Bu yöntem aynı zamanda bir hane halkı anketi olarak da değerlendirilmektedir. 2013 yılında toplamda 10.488 Lichtenberg sakini bütçeleme sürecinde yer almıştır (Buergerhaushalt).

İlgili yerleşim yerinde program bütçelemenin ortaya çıkmasından bu yana, seçilmiş temsilciler, en iyiler listesindeki önerilerin \%90'ını gerçek bütçeye dâhil etmişlerdir. Bununla birlikte, katılımcı bütçelemenin yasal olarak kurumsallaşması sağlanmıştır. 2005 yılından itibaren ise ilçe meclis üyeleri, yerleşiklere katılım firsatları sunmak ve onları katılım hakları konusunda bilgilendirmekle yükümlü hale getirilmişlerdir (Buergerhaushalt).

Almanya'da bütçe planlamasına halkın katılımına ilişkin yasal düzenlemeler söz konusu değildir. Ayrıca yerel yönetim bütçelerinin hazırlanmasına yönelik detaylı yasal prosedürler de bulunmamaktadır. Usullerin değişiklik göstermesi dolayısıyla katılımcı bütçenin uygulanmasında da farklılıklar gözlemlenmektedir (Scherer ve Wimmer, 2012, s.97).

Bütçe kanununun belediye ve kent konseylerinin denetiminde olması sebebiyle katılımcı bütçeleme Almanya'da doğrudan demokrasiyi temsil etmemektedir. Katılımcı bütçe uygulaması, halkın fikir ve önerilerini nasıl açıkladığı ve bunların bütçeye nasıl dahil edilebileceği hususlarına göre çeşitlilik göstermektedir (Scherer ve Wimmer, 2012, s.100).

Almanya 2008 yılından itibaren katılımcı bütçeleme durum raporları yayınlamakta ve önceki yıllara göre kaydedilen gelişmeleri ortaya koymaktadır. Durum değerlendirmesi, katılımcı bütçelemenin içermesi gereken unsurlara göre yapılmaktadır. Raporlamada; belediye bünyesinde katılımcı bütçeleme konusunda gerekli tartışmaların yapılıp yapılmadığı, katılımcı bütçelemeye ilişkin bir konsey kararının olup olmaması, halkın sürece katılım olanakları (halk sadece çevirim içi katılım mı sağlıyor yoksa interaktif katılım da teşvik ediliyor mu?), halkın sürece ne düzeyde dahil edildiği (yönetimin sunmuş olduğu önerilerin önceliklendirilmesi, bu 
önerilerin tartışılması ve kendi önerilerinin sunulabilmesinin mümkün olup olmaması), katılımcı bütçelemenin sürekliliğe sahip olup olmadığı ve katılımcı bütçelemeyle alakalı planlamanın bulunup bulunmaması ya da yerel yönetim gündeminde yer verilip verilmemesi gibi kriterler esas alınmaktadır. 2015 raporunda araştırmaya 435 yerel yönetim birimi dâhil edilmiştir. Katılımc1 bütçeyi bünyesinde tartışmaya açan yerel yönetimlerin sayısı 2014 yılında 75 iken 2015 yılında bu sayı 128'e ulaşmıştır. 435 yerel yönetimden 116'sı katılımcı bütçe sürecini hali hazırda uygulamakta ya da buna ilişkin somut planlamalar yapmaktadır (BPB ve SKEW, 2015, ss.4-5-7).

\subsection{TÜRKIYE}

8 Ekim 2006 tarihinde yürürlüğe giren Kent Konseyi Yönetmeliği’nde, bu Konseyin amaçları arasında; demokratik katılımın geliştirilmesi, yönetişim, kentin temel strateji ve faaliyet planlarının belirlenmesinde, uygulama ve izleme süreçlerinde tüm kenti kapsayan ortak bir aklın oluşturulmasına katkı sağlanması unsurları sayılmaktadır. Ancak Kent Konseyi yapılanmasında karar alma süreçlerine halkın doğrudan katılımı tam anlamıyla sağlanamamakta ve temsili katılım söz konusu olmaktadır. Doğrudan halk katılımını temin edebilmek üzere hem dünya genelinde hem de ülkemizde birtakım çalışmalar yapılmaktadır. TUSENET projesi bu çalışmalardan biridir.

Türk-İsveç Yerel Yönetimler Ortaklık Ağları Projesi olarak ifade edilen TUSENET Projesi, 22 Türk ve beş İsveç belediyesini altı değişik başlık altında bir araya getirerek işbirliği projelerinin üretilmesini hedeflemektedir. 2007 yılı başında Antalya'da düzenlenen açılış konferansıyla tanıtılan TUSENET, bahsedilen ortaklık kapsamında, üretilen projeler vasıtasıyla Avrupa Birliği hibe fonlarından yararlanılması amacını taşıyan bir şemsiye proje olma niteliği taşımaktadır. Bu şemsiye proje ile yerel yönetim hizmet alanına giren konularda teknik yardım ve görüş alışverişinin yapılması yanında yerel demokrasinin geliştirilmesi de amaçlanmaktadır (Altındağ Belediyesi, 2008).

TUSENET projesi altında gerçekleştirilen TUSEPART Projesi ile de katılımcı bütçe özelinde işbirliği geliştirilmesi amaçlanmıştır. TUSEPART kapsamında İsveç’in Umea belediyesi ile Altındağ (Ankara), Osmangazi (Bursa), Nilüfer (Bursa), Yıldırım (Bursa) ve Tepebaşı (Eskişehir) belediyelerinin ortaklığı söz konusu olmuştur (Altındağ Belediyesi, 2008).

Belediye kaynaklarından elde edilen bilgilere göre bu projeler kapsamında seminer ve eğitimler düzenlenmesine karşın somut uygulamalar hayata geçirilememiştir. Örneğin Tepebaşı Belediyesi, katılımcı bütçe uygulaması ile 2009 yılında Fevzi Çakmak Mahallesi'nde bulunan ve 11 dönümlük alana yapılması düşünülen spor tesisleri için, 13-25 yaş arasındaki gençlere, tesisi projelendirme ve harcama yetkisi verileceğini resmi internet sitesinden duyurmuş ancak bu uygulamanın gerçekleştiğine yönelik bulgulara ulaşılamamıştır. Elde edilen geri bildirimler, projeler yoluyla etkin sonuçlara ulaşılamamasının altında projelerin amaçlarına uygun olarak kullanılmamasının yer aldığını ve yönetici değişikliklerinin de proje yürütme süreçlerini olumsuz yönde etkilediğini göstermektedir.

Nilüfer Belediyesi, kent merkezindeki 42 mahallede oluşturduğu Mahalle Komiteleriyle halkın, yaşadıkları bölgedeki hizmet önceliklerini kendilerinin belirlemesini ve doğrudan kent yönetimine katılmasını olanaklı kılmıştır. Nilüfer Kent Konseyi, Kadın Meclisi, Gençlik Meclisi ve Mahalle Komitelerinde alınan kararlar doğrudan Nilüfer Belediye Meclisi gündemine taşınmaktadır. Böylece Nilüfer halkı kent yönetiminde doğrudan söz sahibi olarak kent adına alınan kararlara doğrudan katılabilmektedir (Nilüfer Belediyesi). 
Nilüfer Belediyesi Mahalle Komiteleri’nin katılımcı bütçeleme uygulamaları örnekleri arasinda;

- Çalı Mahallesi Palangalar Mevkii İmar Planı değişikliğinin, Çalı Mahalle Komitesi tarafından reddedilmesi sonucunda Nilüfer Belediye Meclisi gündemine alınmaması,

- Gazi Caddesine ilişkin yeniden düzenleme sürecinin, Cumhuriyet Mahalle Komitesi ve bölge halkının katıldığı toplantılar ve anket çalışmalarıyla yürütülmesi sonucunda bu düzenlemenin caddedeki 180 ağacın kaldırılmadan yapılmasının sağlanması,

- Ortanca Parkı'nın altına otopark yapılmasına ilişkin Belediye Meclisi kararının, ağaç köklerinin gelişimini sınırlandıracağı gerekçesiyle, bölgede yaşayan site sakinleri ile Mahalle Komitesi'nin ortak girişimleriyle bozularak, parkın altına otopark yapılmadan revizyona gidilmesi kararının aldırılması sayılabilir.

Bunlara ek olarak 1 Kasım 2014 - 1 Nisan 2017 tarihleri arasında yapılan 958 komite toplantısında 2060 adet karar alınmış ve kararların 1730'u Nilüfer Belediyesi'ne, 330'u ise diğer kurumlara yönlendirilmiştir. Alınan kararların ne kadarının uygulamaya geçirildiğine yönelik sayısal verilere ulaşılamamıştır.

Türkiye'de yerel yönetimlerde katılımcı bütçeleme uygulamasına yönelik ilk pratik örnek ise Çanakkale Belediyesi tarafından gerçekleştirilmiştir. 2007 yılında merkezi yönetim tarafından yürürlüğe konulan "Yerel Yönetimlere Destek Projesi" kapsamında katılımc1 bütçeleme uygulamasına pilot belediye olarak Çanakkale Belediyesi seçilmiştir (Yalçın, 2015, s.324).

Katılımcı bütçe uygulaması, Fevzipaşa Mahallesi'nde gerçekleştirilmiş ve mahalledeki 16 yaş üstü bireylerin oylamaya katılımı söz konusu olmuştur. Oylamaya katılım oranı ise \%34,4'tür. Oylamada katılımcılara altı seçenek sunulmuştur. Bunlar; (i) kentsel altyapı, (ii) ortak kullanım alanları, (iii) toplu taşıma, (iv) yol-kaldırım-trafik, (v) çevre koruma ve çevre sağlığı, (vi) sosyal hizmetler olarak belirlenmiştir. "Ortak kullanım alanlarının geliştirilmesi” $\% 43,8$ oranla en fazla oy alan seçenek olmuştur. En fazla oy alan ikinci seçenek ise \%29,6 ile sosyal hizmetlerin geliştirilmesi seçeneğidir (Uysal, 2013, s.145). Mahallelinin tercihleri doğrultusunda, Sarıçay kıyısının ve Zafer Meydanı'nın düzenlenmesi, ayrıca mahallelinin eğitim ve kültürel etkinlikleri için kullanabileceği bir merkezin oluşturulması projeleri Çanakkale Belediyesi'nin yatırım programına alınmıştır (Akman'dan aktaran Uysal, 2013, s.145).

Ülkemiz yerel yönetimlerince hazırlanan Yerel Eşitlik Eylem Planları, katılımcı bütçeleme kapsamında değerlendirilebilecek uygulamalardan biridir. Bu eylem planlarının temelleri Kadın Dostu Kentler Programı'na dayanmaktadır. Bu program ise Birleşmiş Milletler Binyıl Kalkınma Hedeflerinden hareketle, 2006 yılında toplumsal cinsiyet eşitliği prensiplerinin yerel yönetimlerin planlama ve programlama süreçlerine dâhil edilmesi ve bu sürece paralel olarak yerel yönetimler ile kadın örgütlerinin güçlendirilmesi ve aralarındaki işbirliği fırsatlarının arttırılması amacını taşımaktadır. Kadın dostu kentler; kentlerdeki ekonomik, sosyal, kültürel ve siyasi fırsatlardan kadınların da eşit bir biçimde yararlanabileceği yerleşimlerdir. Bu kentleri mümkün kılmanın yolu ise katılımcı yönetimi sağlayacak mekanizmaların yerel düzeyde oluşturulması, yerel yönetimlerin planlama ve karar süreçlerine kadınların ve toplumsal cinsiyet eşitliği bakış açısının dâhil edilmesi ve yerel yönetimler ile kadın kuruluşları arasında diyalog ve işbirliği alanlarının geliştirilmesinden geçmektedir (Nevşehir Belediyesi, 2014, s.6).

Program kapsamında örneğin Antalya İli 2013-2017 Yerel Eylem Planı ile kadınların temel kentsel hizmetlerin planlanması, izlenmesi ve değerlendirilmesi süreçlerine katılımlarının arttırılması hedefleri belirlenmiştir. Bu doğrultuda; imar planlama, altyapı, 
çevre, ulaşım, güvenlik, kültür sanat ve spor alanlarındaki ihtiyaçlarını, hizmete erişim engellerini ve hizmetin ihtiyacı ne derece karşıladığını tespit etmek üzere analizlerin ve memnuniyet araştırmalarının yapılması öngörülmüştür. İzmir İli 2013-2017 Yerel Eylem Planında, kadınların talepleri alınarak spor parkları, çocuk parkları ve deniz kenarında dinlenme parkları gibi yeni uygun park alanlarının oluşturulması hedeflenmiştir. Bursa Büyükşehir Belediyesi 2013-2015 Yerel Eylem Planında, merkez ilçelere bağlı belirlenen pilot mahallelerde yaşayan kadınların ihtiyaç duyduğu hizmetlere (ulaşım, barınma, güvenlik, bakım, rekreasyon vb.) yönelik düzenli aralıklarla (2 yılda bir) anket çalışmaları yapılması, kadınların öncelikli ihtiyaçlarının belirlenmesi faaliyetleri hedeflenmiştir.

\section{SONUÇ VE ÖNERİLER}

Katılımcı bütçeleme, halkın doğrudan bütçe harcamaları ve öncelikleri ile ilgili kararlara aktif katılımı anlamına gelmektedir. Burada amaç, kamu hizmetlerinde şeffaflık ve etkinliğin temini ile demokratik katılımın ve aktif vatandaşlığın geliştirilmesidir.

Ulaşım, çevre düzenlemesi, su temini, yol yapımı, altyapı, temizlik, bakım-onarım, kültürel-sanatsal etkinlik gibi belediyenin görev alanına giren hizmetlerin ve bunlara yönelik yatırımların hangilerine öncelik verilmesi gerektiğine yerel yönetim sınırları içerisinde yaşayan yerleşiklerin ihtiyaçları göz önünde bulundurularak karar verildiğinde, bahsedilen hizmetlerin halk üzerinde yaratacağı memnuniyet ve tatmin düzeyi artacaktır. Çünkü vatandaşlar, hizmetlere ilişkin projelerin hayata geçirilmesinden önce bu projeler hakkında detaylı bilgi sahibi olacaklar ve hangi projenin uygulanacağına kendileri karar vereceklerdir. Öte yandan, katılımcı bütçeleme sisteminde kamu gelirlerinin gerçek finansörü konumundaki halkın, bu gelirlerin hangi alanlara aktarıldığını denetlemesi söz konusu olmaktadır. Bu bütçeleme sisteminde proje öneri, plan ve uygulama aşamalarının her birine aktif katılım sağlandığından dolayı, kamu hizmetlerinde ve genel anlamda kamu idaresinde şeffaflık da temin edilmektedir.

İlk olarak 1989 yılında Brezilya'nın Porto Alegre belediyesince uygulamaya geçirilen katılımcı bütçeleme yaklaşımı daha sonraları, Avrupa, Asya ve Afrika Kıta ülkelerine yayılmıştır. Avrupa ülkelerinde katılımcı bütçeleme alanında somut uygulamalar bilhassa son 10 y1l içerisinde gerçekleştirilmiş ve gelişme göstermiştir. Birçok Avrupa ülkesinde benimsenen katılımcı bütçeleme sistemi, Avrupa'nın Londra, Berlin, Lizbon, Paris gibi kalabalık ve gelişmiş şehirlerinde uygulama alanı bulmuştur. Ülkemizde ise katılımcı bütçelemeye ilişkin adımlar 2006 yılından sonra atılmaya başlanmış ancak pratikte yaygınlaştırılamamıştır. Bu nedenle çalışmada, Türkiye'deki katılımcı bütçe uygulamalarına ilişkin olarak halkın yerel bütçenin ne kadarını belirleyebildiği, kaç tane projenin halk tarafından önerildiği ve önerilen projelerin kaçının belediyece kabul gördüğü, hangi oylama ve tercih mekanizmalarının kullanılarak tercihlerin açıklandığı gibi hususlara ait somut çıktılara ve sayısal verilere gereğince yer verilememiştir. Türkiye'de katılımcı bütçeleme uygulamalarının, bu araştırmada bahsedilen Avrupa ülke örneklerinde olduğu gibi çoğalması ve bu konuda sağlıklı verilerin tutulması durumunda ülke karşılaştırmalı performans analizlerinin yapılması kolaylaşacaktır.

Konuya ilişkin Türkiye'de yerel ölçekte farklı kurumlarca önerilen projelerin belediyelerce desteklenmesi, ihtiyaç duyulan katılımcı organların oluşturulması ve bu organların en geniş haliyle kamu harcama yönetim süreçlerine aktif katılımlarının sağlanması gerekmektedir. Bu bağlamda yasal düzenlemelerin ivedilikle yapılarak hayata geçirilmesi, katılımcı bütçeleme yaklaşımının gelişiminde önem taşımaktadır. 


\section{Kaynakça}

Allegretti, Giovanni; Antunes, Sofia. (2014). The Lisbon Participatory Budget: Results and Perspectives on an Experience in Slow But Continuous Transformation. Facts Reports, Special Issue 11, 1-10.

Altındağ Belediyesi. (2008). TUSENET ve TUSEPART. http://www.altindag.bel.tr /haber.asp?islem=1\&haber_ID=1533. Erişim: 28.03.2017.

Baiocchi, Gianpaolo. (2009). Politicizing the Civic: Participatory Budgeting in Porto Alegre. P. Silva, H. Cleuren (Ed.). Widening Democracy: Citizens and Participatory Schemes in Brazil and Chile (115-138). The Netherlands: Brill.

Blakey, Heather .(2008). Participatory Budgeting in the UK: A Challenge to the System?. Participatory Learning and Action, 61-65.

Blore, Ian; Devas, Nick; Slater, Richard. (2004). Municipalities and Finance. London and New York, Earthscan.

BPB; SKEW. (2015). 8th Status Report Participatory Budgeting in Germany. Bonn.

Bredenoord, Jan; Van Lindert, Paul; Smets, Peer. (2014). Latin America. Jan Bredenoord, Paul Van Lindert, Peer Smets (Ed.). Affordable Housing in the Urban Global South: Seeking Sustainable Solutions (219-222). London and New York, Routledge Taylor \& Francis Group.

Buergerhaushalt. Best Practice Examples. http://www.buergerhaushalt. org/en/best_ practice\#n1834. Erişim: 05.04.2017.

Cole, Alistair; John, Peter. (2001). Local Governance in England and France, Routledge.

Eissel, Dieter; Grasse, Alexander. (2011). Local and Regional Governance in EU's Perspective. Chin-peng Chu, Alexander Grasse, Sang-Chul Park, Markus PorscheLudwing (Ed). Local Governance in the Global Context: Theory and Practice (63-98). Berlin, LIT Verlag.

Ergen, Zuhal. (2012). Yönetimden Yönetişime: Katılımcı Bütçeleme Modeli, Maliye Dergisi, Say1: 163, 316-334.

Ghosh, Buddhadeb; Mohanty, Bidyut; Jacob, Nitya. (2011). Local Governance Search for New Path. Concept Publishing Company.

Gilman, Hollie Russon. (2016). Democracy Reinvented: Participatory Budgeting and Civic Innovation in America. Washington, D.C, Brookings Institution Press.

Keblowski, W., \& Van Criekingen, M. (2014). Hope for Democracy: 25 Years of Participatory Budgeting Worldwide. N. Dias (Ed.). Participatory Budgeting PolishStyle. What Kind of Policy Practice has Travelled to Sopot, Poland? (369-377). Sao Bras de Alporter, In Loco Association.

Lerner, Josh (2010), Learning Democracy Through Participatory Budgeting: Who Learns What And So What. Elizabeth Pinnington and Daniel Schugurensky (Ed.). Learning Citizenship by Practicing Democracy: International Initiatives and Perspectives (242251). UK, Cambridge Scholars Publishing.

Napolitano, Antonella. (12.02.2015). Lessons from Paris, Home to Europe's Largest Participatory Budget, The Techpresident, http://techpresident.com/news/25441/parisexperiments-participatory-budget-codesign. Erişim: 30.09.2016.

Nevşehir Belediyesi .(2014). Nevşehir Yerel Eşitlik Stratejik Planı 2013-2017. Nevşehir. 
Nilüfer Belediyesi. Katılımcı Yönetim. http://www.nilufer.bel.tr/nilufer belediyesi-237katilimci_yonetim. Erişim: 31.03.2017.

OECD. (2007). Beyond Public Scrutiny: Stocktaking of Social Accountability in OECD Countries. Working Papers. 146-152.

Özen, Ahmet; Yontar, İbrahim Güray. (2009). Katılımcı Demokrasi Anlayışında Bütçeleme: Katılımc1 Bütçeleme. Maliye Dergisi. Sayı: 156, 280-293.

Participatory Budgeting Project .(2016). Examples of PB, http://www.participatory budgeting.org/about-participatory-budgeting/examples-of-participatory-budgeting/. Erişim: 11.10.2016.

PB Unit. (2010). Participatory Budgeting in the UK-A Toolkit. Second Edition.

PB Network .(2017). What's Hapening in Participatory Budgeting Across England, https://pbnetwork.org.uk/category/geographic/england/. Erişim: 09.04.2017.

Röcke, A. (2014). Framing Citizen Participation (1st ed.). Basingstoke: Palgrave Macmillan.

Sakınç, Süreyya; Aybarç Bursalığlu, Sibel. (2014). Bütçelemede Demokratik Bir Değişim: Kat1lımc1 Bütçeleme, Electronic Journal of Vocational Colleges, http://www.ejovoc.org/ makaleler/ may_2014/pdf/01.pdf. Erişim: 06.04.2017.

Scherer, S.; Wimmer, M. A. (2012). Reference Process Model for Participatory Budgeting in Germany. E. Tambouris, A. Macintosh, S. Øystein (Ed.), 4th IFIPWG8.5 International Conference (97-111). Heidelberg, Springer.

Shah, Anwar; Shah, Sana. (2006). Local Governance in Developing Countries. Anwar Shah (Ed.). The New Vision of Local Governance and the Evolving Roles of Local Governments (1-46). Washington DC, World Bank.

SQW Consulting. (2007). Briefing Note 1 Participatory Budgeting, http://www.sqw.co.uk/ files/1313/8712/1040/54.pdf. Erişim: 09.10.2017.

Strandring, Adam. (12.11.2014). Participatory Budgets in Portugal - A New Route to Public Engagement. The Crick Centre, http://www.crickcentre.org/blog/participatorybudgets-portugal-new-route-public-engagement/. Erişim: 04.04.2017.

TEPAV. (2007). İyi Bir Yönetişim İçin Örnek Bir Model: Katılımcı Bütçeleme, Yönetişim Etütleri Programı, http://www.tepav.org.tr/upload/files/1271229711r9770.Iyi_ Yonetisim_Icin_Ornek_Bir_Model_Katilimci_Butceleme.pdf. Erişim: 06.04. 2017.

The World Bank. (2002). Empowerment and Poverty Reduction. Washington DC.

The World Bank. (2004). State- Society Synergy For Accountability. World Bank Working Paper No.30. USA.

UN-HABITAT. (2004). 72 Frequently Asked Questions About Participatory Budgeting. Urban Governance Toolkit Series. Quito, United Nations Human Settlements Programme.

UN-HABITAT. (2008). Participatory Budgeting in Africa: A Training Companion. Nairobi, United Nations Human Settlements Programme.

Uysal, A. B. (2013). Katılımcı Senaryo Tekniği Yardımıyla Tarihi Kentsel Alan İçin İyileştirme Stratejisinin Belirlenmesi. METU Journal of the Faculty of Architecture. $30(2), 137-162$. 
Veron, Pauline. (09.03.2015). Why Paris is Building the World's Biggest Participatory Budget. New Cities Foundation, http://www.newcitiesfoundation.org/why-paris-isbuilding-the-worlds-biggest-participatory-budget/. Erişim: 30.09.2016.

Wampler, Brian. (2007). A Guide to Participatory Budgeting. Anwar Shah (Ed.). Participatory Budgeting (21-54). Washington, D.C, World Bank.

Worldwatch Istitute. (2007). State of the World 2007: Our Urban Future. Linda Starke (Ed.). Washington D.C., W.W. Norton \& Company.

Xavier Pinto Coelho, Luana. (2013). Mundus Urbano: (Re) Thinking Urban Development. Luana Xavier Pinto Coelho, Lorena Melgaço Silva Marques, Regina Orvananos Murguia (Ed.). Participatory Budgeting in South America and Europe: A Social Inclusion Perspective (73-84). Berlin, Frank \& Timme.

Yalçın, A. Z. (2015). Yerel Yönetimlerde Katılımcı Bütçeleme. Yönetim ve Ekonomi. 22(2), 311-329.

Yves, Cabannes. (2015). Another City is Possible: Participatory Budgeting. Cabannes Yves, Cecilia Delgado (Ed.). Seville, At One Time One of The Most Advanced European Participatory Budgeting Experience, Unfortunately Interrupted (128-134). Lizbon, The Charles Leopold Mayer Foundation. 